\title{
The role of continuous professional development of teachers in educational change: A literature review
}

\author{
Serkan Ucan ${ }^{\mathrm{a}}$ \\ ${ }^{\mathrm{a}}$ Faculty of Education, Harran University, Sanliurfa, Turkey
}

\begin{abstract}
The notion that teachers play key role in the implementation of any educational reform is not a controversial issue anymore. Teachers always undertake an important mission for bringing about change to education systems, since they are the ones who will decide whether or not accept the change. According to many scholars hence, teachers and their continuous professional development (CPD) are crucial in determining the success of any educational reform directly and the future of society indirectly. In the light of the scholarly literature, the purpose of this paper is to show the importance of teachers' CPD in the implementation of educational reforms and scrutinise one of the most cited factors, school culture, in influencing CPD of teachers.
\end{abstract}

\section{ARTICLE HISTORY}

Received 7 December 2016 Accepted 25 December 2016

\section{KEY WORDS}

Continuous professional developments of teachers; educational change; school culture

\section{Introduction}

Almost every teacher comes across a number of challenges when taking part in the implementation of an educational reform. In order to have a successful implementation process, it is important to consider what changes teachers will experience in their teaching and learning process before introducing an educational innovation. As Fullan (2016, p.97) argues that "educational change depends on what teachers do and think", the role of teachers and particularly their continuous professional development (CPD) have become noteworthy to be considered in the implementation of any educational reform. According to Bell and Gilbert (2005), teacher development is a continuing process in which teachers always seek new ways and methods to improve the learning of their students. During CPD process, teachers acquire new understanding and beliefs regarding the potential of new teaching methods and materials in students' learning, as well as look for developing themselves not only professionally but also socially and personally all together. However, as it is the case for most teachers, they also encounter many difficulties they have to cope with before achieving a successful professional development.

In the light of the scholarly literature, the aim of this paper is to demonstrate how important the role of teachers' CPD is in the implementation of educational reforms, such as new curriculum, and what role the school culture plays in CPD of teachers. 
In the next sections, I will first attempt to describe the role of teachers' CPD in educational change. Then, I shall look at the literature to highlight the importance of having supporting school culture for the successful CPD of teachers.

\section{CPD and educational change}

It is not easy to find a single definition of CPD in the literature, since there are several terms associated with CPD, such as in-service education and training, teacher development, professional development, staff development, career development and lifelong learning, which all of them have overlapping meanings and different definitions (Bolam \& McMahon, 2004). Day and Sachs (2004) suggest a general definition of CPD, which I think, embraces all of the above terms. According to this definition, "CPD is as a term used to describe all the activities in which teachers engage during the course of a career which are designed to enhance their work" (ibid, p.3). In addition to this definition, they mention three imperatives that may be seen as a function of CPD of teachers. The first imperative is to align teachers' practice with educational policies; the second is to help teachers improve their performance in order to improve learning outcomes of students; and the last one is to improve the prestige of teaching profession.

Currently, teachers' CPD is being given increasing importance by almost all governments throughout the world, as it is seen as indispensable for responding "the ever-changing needs of students in today's school" (Swafford, 2000, p.113). Goodson and Hargreaves (2002) describe teaching as a 'core profession' which plays a key role in the knowledge society, and teachers as 'midwives' of that society without whom the future of society will be 'malformed and stillborn'. Moreover, Day and Sachs (2004) argue that the impact of globalization shapes the educational policies in general and teachers' CPD in particular. According to them, considering the recent reforms in education, such as curriculum changes, CPD has become no longer an option, but an expectation of teaching profession.

In order to understand how the educational change affects teachers' CPD and their understanding of the role that they play, first of all, we should look at why and by whom the educational change is initiated. If we scrutinize educational change in the current literature, we can easily see that it can be initiated from variety of reasons. According to Fullan (2016), for instance, "change may come about either because it is imposed on us... or because we voluntarily participate in or even initiate change when we find dissatisfaction, inconsistency, or intolerability in our current situation" (p.19). In other words, educational change can be initiated by external factors, such as social events or government initiatives and imposed upon teachers, or it can be self-initiated by teachers such as "accepting of a professional dissatisfaction or a problem" (Bell \& Gilbert, 2005, p.16).

Nevertheless, whatever the reason is for educational change, teachers always find themselves in a position of being simultaneously both 'the subject' and 'the agent of change' (Sikes, 2013). While on the one hand teachers have an important task to implement the innovation, on the other hand they are also required to make changes in their beliefs, attitudes, knowledge and skills, and more importantly in their teaching practices. At this point, many authors recognize the importance of professional development of teachers in the implementation of educational change. Fullan and Hargreaves (2013), for instance, argue 
that "successful change involves learning how to do something new. As such, the process of implementation is essentially a learning process. Thus, when it is linked to a specific innovation, teacher development and implementation go hand in hand" (p.1). They argue essentially that regardless of the direction of the change, teachers' $\mathrm{CPD}$ and the implementation of educational innovation must be considered inseparable, since the process of implementation requires teachers to put new ideas and knowledge into practice. So, the implementation process is seen, at the same time, as a learning process, and educational change as a teacher development.

In the extant literature, it is obvious that CPD of teachers and educational changes are recognised as quite interrelated and having a crucial function in determining each other's success. Nevertheless, in order to understand this relationship more deeply, we should be aware of the factors affecting the implementation process undertaken by teachers. In the next section, I will look at the role of school culture, one of the most quoted factors influencing CPD of teachers.

\section{School culture}

School culture can be defined as "the basic assumptions, norms and values, and cultural artefacts that are shared by school members, which influence their functioning at school" (Maslowski 2001, p.8-9). It is considered influential in the implementation of educational reforms in either supporting or impeding the change process (Hennessy et al., 2005; Teach First, 2010; Wan, 2011). It is widely accepted that although teachers have suitable training opportunities as well as necessary beliefs, knowledge and skills, it may be unlikely to have a successful implementation of educational change without a positive and collaborative school culture.

If we look at the literature, we can easily see that many scholars recognize the importance of school culture in creating the circumstances in which educational innovations may flourish and become constant. Day and Sachs (2004), for example, emphasize the importance of the school culture for teachers' learning. They suggest that "just as conditions in the classroom affect the ability of teachers to provide the best learning opportunities for students, so the school culture provides positive or negative support for its teachers' learning" (ibid, p.10). In addition, Bolam and McMahon (2004) point out that in order to have a sustainable implementation of educational reform, there is a need for a new form of comprehensive professional development which affects "not only the knowledge, attitudes and practices of individual teachers, administrators and so on, but also cultures and structures of organisations in which they work" (p.34). Adey (2004) highlights the importance of school environment for the educational change. He claims that "teachers rarely if ever are able to make real changes in their pedagogy unless the school environment in which they find themselves is, at the very least, tolerant to innovation" (ibid, p.165).

Furthermore, besides change at the individual level, Fullan (2016) emphasizes the importance of organizational change in order to provide supportive and stimulating environment to encourage teachers to change their practices. However, he argues that most strategies for educational innovations have concentrated on only the structures of schools, formal requirements and other activities, such as teacher training sessions, rather than existing culture of schools which requires new values and practices for the success of the educational innovation. Therefore, he suggests that if the changes, brought by educational innovation, are 
to become constant, teachers and principle will need not only to 'restructure' current school schedules and curriculum, but also 'reculture' their school to create and foster purposeful learning communities.

In the literature, we can identify many difficulties that teachers come across in their CPD because of the culture and ethos of the school in which they work. Brookfield (1995) presents three cultural barriers that keep teachers away from engaging in a critically reflective practice. The first barrier is 'the culture of silence' in which teachers learn not to talk too much about how they teach, and discuss their practices in public. The second barrier is 'the culture of individualism' where teachers work as isolated individuals and are not willing to collaborate with their colleagues. And the last barrier is 'the culture of secrecy' in which encouraging self-disclosure of teachers is limited, since teachers do not feel comfortable with the people working with them. Similarly, Day and Sachs (2004) point out the isolation of teachers from their colleagues which hinder them to discuss, think about and try out new practices in a collaborative way. Furthermore, Swafford (2000) ascribes the teachers' failure in the implementation of new ideas to having no support from their colleagues when they attempt to learn new knowledge and skills, and change their practices.

It can be seen from above that there are many problems related to school culture, such as isolation of teachers in the classroom, lack of collaboration and support among colleagues, and discouragement of self-disclosures that teachers must cope with before achieving successful CPD. Nevertheless, many authors recommend some solutions to teachers and school managers to tackle these problems that enable them to create positive school culture. In terms of teacher learning, Smylie (1995, cited in Kelchtermans, 2004) suggests four conditions that enhance teacher learning. First, individual teachers should be encouraged to collaborate with, and learn from each other constantly. Second, the environment, in which teachers work together in groups and communicate with each other easily, should be provided. Third, teachers should be involved in decision making process, and acknowledge the presence of shared power and authority. Finally, individual teachers should be provided with certain degree of autonomy and choice for their professional learning.

In addition, Day and Sachs (2004) present 'expanded view of professional learning' that locates $\mathrm{CPD}$ in three different settings; direct learning (through e.g. workshop, conference), learning in school (through e.g. peer coaching, mentoring), and learning out of school (school-university partnership, social networks). They argue that in today's world, teacher should engage with all of these activities especially 'learning in school' to align their professional development with the demands of educational reforms. Furthermore, Kelchtermans (2004) emphasizes the importance of collegiality in CPD of teacher. He describes collegiality as the cure of all 'diseases' in schools. He maintains that "the quality of collegial relations among staff members in school as well as their collaboration are widely acknowledged as very powerful determination of school development, successful implementation of innovations, and job satisfaction" (ibid, p.222).

Furthermore, Fullan (2016) emphasizes the importance of school leadership in establishing appropriate school climate and determining the quality of teaching and learning. He describes school principle as being a person who is "most likely to be in a position to shape the organizational conditions necessary for success, such as the development of shared goals, collaborative work structures and climates, and procedures for monitoring re- 
sults" (ibid, p.83). As Pelgrum (2001) puts forwards, school leadership is usually considered as the most important change agent in the early stages of the implementation of educational innovations, although teachers play one of the crucial roles in the entire educational change process.

Lastly, considering the professional development models, Bell and Gilbert (2005) suggest three aspects of teacher development; personal, social and professional development. For the successful social development, they argue that teachers must see their isolation in the classroom as a problematic, then value collaborative way of working, and lastly initiate collaboration with their colleagues. Additionally, in his professional development model, Adey (2004) emphasizes the nature of the environment into which innovation is being initiated. He suggests two main aspects that either support or inhibit teachers' attempt to change; "one is the presence or absence of collegial support and the opportunity to share experiences informally but frequently; other is more related to the extent to which innovation is embedded in the management structure of school" (ibid, p.166).

Consequently, there is no doubt that in the implementation of any educational reform, teachers undertake crucial and difficult task to change their practices, as well as to cope with many difficulties that may arise because of the structure and culture of the schools in which they work. Considering this, it is suggested that any educational reform must take into account the school environment that can encourage or discourage teachers to collaborate with and support each other during their professional development as well as implementation of new educational innovations. As Fullan (2016) argues, "social learning and shared meaning are at the centre of school and system success" (p.49), therefore, in order to have an effective CPD and educational innovation, teachers must exchange their ideas, support each other and create positive atmosphere during their work, rather than work as isolated individuals. Moreover, as Dillon (2000) argues that "teacher development is a management responsibility" (p.94), school management has to provide teachers with these opportunities that they can create an environment in which meaningful interactions among staffs can take place. I shall end this section with a quote that, I think, emphasizes this idea and recognize the importance of positive school culture for teachers' CPD along with many other factors;

\footnotetext{
"The culture and ethos of the school, the quality of leadership and administration, the availability of resources, whether or not there is a calm and orderly atmosphere, and the level of workload will all influence whether teachers have any space or energy to devote to their professional development" (Sparks \& Loucks-Horsley, 1990, cited in Bolam \& McMahon, 2004, p.46).
}

\section{Conclusion}

This paper aimed to present a review of the scholarly literature to illustrate the importance of teachers' CPD in the implementation of educational reforms, as well as scrutinise the role of school culture in influencing CPD of teachers. In the extant literature, it is suggested that CPD of teachers and educational change are quite interrelated and have a crucial function in determining each other's success. As Sikes (2013) puts forward, teachers usually find themselves in a position of being simultaneously both the subject and the agent of change du- 
ring educational change, since on the one hand, they have an important mission of implementing the change, and on the other hand, they also need to make changes in their beliefs, attitudes, knowledge, skills and more importantly their teaching practices simultaneously. Hence the current literature strongly suggests that teachers' CPD and the implementation of educational change should be considered inseparable and the process of implementation needs to be seen as a learning process for teachers who are required to put new ideas and knowledge into practice in an effective manner.

This review also highlight the crucial role played by school culture in enabling successful CPD of teachers. Although, teachers may have a plenty of opportunities for their $\mathrm{CPD}$, the literature suggests that it is very difficult to have an effective professional development without a positive and collaborative school culture. The current literature mentions several problems associated with school culture, such as isolation of teachers in the schools, lack of collaboration and support among colleagues, and discouragement of selfdisclosures, which teachers must cope with before achieving successful CPD. Nevertheless, in coping with these difficulties, it also provides teachers and school leadership with a number of solutions, such as presenting teachers autonomy and choices for their professional development, promoting collegial support and effective collaboration among teachers, establishment of appropriate school climate by school leadership.

Accordingly, given the importance of teachers' role in the implementation of educational reforms, this paper calls for future research to further explore the optimal conditions under which effective CPD processes can occur. Moreover, since teachers are likely to experience various challenges during their $\mathrm{CPD}$, it is also important for researchers and all stakeholders to clearly identify the sources of these challenges and produce practicable solutions in their school districts, such as recommending ways of setting and instilling a positive and collaborative school culture. This line of research is likely to present potential contributions to create best possible CPD experiences by which teachers can develop themselves continuously and become creative, innovative, and thoughtful professionals who can make a positive impact on the quality of teaching and learning processes.

\section{References}

Adey, P. (2004). The professional development of teachers: practice and theory. London: Kluwer.

Bell, B., \& Gilbert, J. (2005). Teacher development: a model from science education. Taylor \& Francis eLibrary.

Bolam, R., \& McMahon, A. (2004). Literature, definitions and models: towards a conceptual map. In C. Day, and J. Sachs, (Eds.), International Handbook on the Continuing Professional Development of Teachers, (pp. 33-64). Berkshire: Open University Press.

Brookfield, S. (1995). Becoming a Critically Reflective Teacher. San Francisco, CA: Jossey-Bass.

Day, C., \& Sachs, J. (2004). Professionalism, performativity and empowerment: discourses in the politics, policies and purposes of continuing professional development. In C. Day and J. Sachs, (Eds.), International Handbook on the Continuing Professional Development of Teachers, (pp. 3-33). Berkshire: Open University Press.

Dillon, J. (2000). Managing Science Teachers' Development. In Millar, J. (Eds.). Improving science education: The contribution of research. (pp. 94-109). McGraw-Hill Education (UK). 
Fullan, M., \& Hargreaves, A. (2013). Teachers Development and educational change. New York: Routledge.

Fullan, M. (2016). The new meaning of educational change (5th ed.). New York and London: Teachers College Press.

Goodson, I., \& Hargreaves, A. (2002). Series editors' preface. In G.B. Hoban, (Eds.), Teacher Learning for Educational Change, (pp. viii-xi). Buckingham: Open University Press.

Hennessy, S., Ruthven, K. \& Brindley, S. (2005). Teacher perspectives on integrating ICT into subject teaching: commitment, constraints, caution, and change. Journal of Curriculum Studies, 37(2), 155-192.

Kelchtermans, G. (2004). CPD for professional renewal: moving beyond knowledge for practice. In C. Day, and J. Sachs, (Eds.), International Handbook on the Continuing Professional Development of Teachers, (pp. 217-237). Berkshire: Open University Press.

Maslowski, R. (2001). School culture and school performance: An explorative study into the organizational culture of secondary schools and their effects, Twente: University of Twente Press.

Pelgrum, W. J. (2001). Obstacles to the integration of ICT in education: results from a worldwide educational assessment. Computers \& Education, 37, 163-178.

Sikes, P.J. (2013). Imposed change and the experienced teacher. In M. Fullan, \& A. Hargreaves, (Eds.), Teachers Development and educational change, (pp. 36-55). New York: Routledge.

Smylie, M. (1995). Teacher learning in the workplace: implications for school reform. In T. R. Guskey \& M. Huberman, (Eds.), Professional Development in Education: New paradigms and practices, (pp. 91-113). New York: Teachers College Press.

Sparks, D., \& Loucks-Horsley, S. (1990). Models of staff development. In W.R. Houston, (Eds.), Handbook of research on Teacher Education. London: Macmillan.

Swafford, J. (2000). Teachers supporting teachers through peer coaching. In B. Moon, J. Butcher, \& E. Bird, (Eds.), Leading Professional Development in Education, (pp.107-115). London: RoutledgeFalmer.

Teach First (2010). Ethos and Culture in Schools in Challenging Circumstances: A Policy First Publication London: Teach First.

Wan, W. Y. S. (2011). Teachers' perceptions and experiences of continuing professional development (CPD): opportunities and needs in Hong Kong primary schools (Doctoral dissertation, University of Nottingham). 


\section{ÖZET}

\section{Eğitimsel Değişimlerde Öğretmenlerin Sürekli Mesleki Gelişiminin Rolü: Bir Literatür Taraması}

Anahtar kelimeler: Eğitimsel değişim, öğretmenlerin sürekli mesleki gelişimi, okul kültürü

$\mathrm{Bu}$ makale, öğretmenlerin devam eden mesleki gelişimlerinin eğitimsel değişim süreçlerindeki önemini göstermek ve okul kültürünün öğretmenlerin mesleki gelişimlerini etkilemedeki rolünü incelemek için bir akademik literatür taraması sunmayı amaçlamaktadır. Mevcut literatürde, öğretmenlerin sürekli mesleki gelişiminin ve eğitimsel değişikliklerin birbiriyle oldukça ilişkili olduğu ve birbirlerinin başarısını belirlemede çok önemli bir işleve sahip oldukları açıkça görülebilir. Sikes’in (2013) öne sürdügü gibi, öğretmenler genellikle eğitimsel değişim sürecinde kendilerini değişimin aynı anda hem konusu, hem de aktörü konumunda bulurlar. Öğretmenler bir yandan değişimin uygulanması yönünde önemli bir göreve sahipken, öte yandan kendilerinden inançları, tutumları, bilgi ve becerilerinde ve daha da önemlisi sınıftaki uygulamalarında aynı anda değişiklik yapmaları beklenir. Bu nedenle, öğretmenlerin sürekli mesleki gelişimi ve eğitimsel değişimlerin uygulama sürecinin birbirinden ayrı olarak düşünülmemesi gerektiği ve aynı zamanda uygulama sürecinin de yeni fikirleri etkili bir şekilde uygulamaya koyması gereken öğretmenler için bir öğrenme süreci olarak düşünülmesi gerektiği yaygın olarak kabul edilir.

$\mathrm{Bu}$ literatür incelemesi, aynı zamanda, öğretmenlerin devam eden mesleki gelişimlerini başarılı bir şekilde gerçekleştirmesinde okul kültürünün önemi vurgulamaktadır. Öğretmenler, mesleki gelişimleri için uygun birçok eğitim fırsatına sahip olsalar da, güncel literatürde, pozitif ve işbirliğine dayalı bir okul kültürü olmaksızın etkili bir mesleki gelişim süreci yaşanmasının onlar açısından çok zor olduğunu görülmektedir. Öğretmenlerin başarılı bir mesleki gelişimi gerçekleştirmeden önce, okul kültürüyle ilintili, üstesinden gelmek zorunda oldukları farklı sorunlar arasında; okullarda öğretmenlerin tecridi, meslektaşlar arasında işbirliği ve destek eksikliği, kendi duygu ve düşüncelerini açığa vurma noktasında yaşadıkları cesaretsizlik gibi sorunlardan güncel literatürde sıklıkla bahsedilmektedir. Bu zorluklarla baş edebilmek için, mevcut literatür aynı zamanda öğretmenlere özerkliklerinin ve mesleki gelişimlerine yönelik seçimlerin sunulması, meslektaşlar arasındaki destek ve etkili işbirliğinin teşvik edilmesi, okul yönetimi tarafından uygun bir okul iklimi oluşturulması gibi bir dizi çözüm önerisi getirmektedir.

Eğitim reformlarının uygulanmasında öğretmenlerin rolünün önemi göz önüne alındığında, araştırmacıların gelecekte yapacakları çalışmalarda etkili mesleki gelişim süreçlerinin oluşabileceği en uygun koşulları ayrıntılı bir şekilde incelemeleri önem arz etmektedir. Ayrıca, öğretmenlerin mesleki gelişim sürecinde çeşitli zorluklarla karşılaşabilecekleri gerçeği düşünüldügüunde, hem araştırmacıların hem de öğretmenler ve okul yönetimi de dahil olmak üzere tüm paydaşların, ortaya çıkabilecek zorlukların kaynaklarını net bir şekilde araştırıp, belirlemeleri ve var olan zorlukların aşılması noktasında pratik çözümler üretmeleri önemlidir. Bu alanda gelecekte yapılacak olan araştırmalar, öğretmenlerin öğretim ve öğrenme süreçlerinin kalitesini olumlu yönde etkileyecek yaratıcı, yenilikçi ve girişimci profesyoneller haline gelmesine yardımcı olabilecek en iyi ve etkili mesleki gelişim deneyimlerinin oluşturulmasına önemli katkılar sağlayacaktır. 